\section{B A Institute of \\ YK Business Administration \\ 六下 \\ Karachi \\ Leadership and Ideas for Tomorrow}

Business Review

Volume 7 Issue 1 January-June 2012

$1-1-2012$

\title{
A comparative study of leading business schools of Pakistan: The market acceptability of IBA business graduates in the corporate sector
}

\author{
Yaseen Ahmed Meenai \\ Institute of Business Administration, Karachi, Pakistan \\ Rizwan Raheem Ahmed \\ Institute of Business Administration, Karachi, Pakistan
}

Follow this and additional works at: https://ir.iba.edu.pk/businessreview

Part of the Business Commons, and the International and Comparative Education Commons

\section{(c) (1)}

This work is licensed under a Creative Commons Attribution 4.0 International License.

\section{Recommended Citation}

Meenai, Y. A., \& Ahmed, R. R. (2012). A comparative study of leading business schools of Pakistan: The market acceptability of IBA business graduates in the corporate sector. Business Review, 7(1), 116-127. Retrieved from https://doi.org/10.54784/1990-6587.1306

This article is brought to you by iRepository for open access under the Creative Commons Attribution 4.0 License and is available at https://ir.iba.edu.pk/businessreview/vol7/iss1/10. For more information, please contact irepository@iba.edu.pk. 


\title{
CASE STUDY
}

\section{A Comparative Study of Leading Business Schools of Pakistan: the market acceptability of IBA Business Graduates in the Corporate Sector}

\author{
Yaseen Ahmed Meenai \\ Institute of Business Administration, Karachi, Pakistan \\ Rizwan Raheem Ahmed \\ Institute of Business Administration, Karachi, Pakistan
}

\begin{abstract}
In Pakistan, establishing and running business schools in private sector flourished because of the increasing propensity of students for business studies to commence their career as executives in corporate and other sectors. But, this has become a commercial activity. There are only few public and private institutes which are the role model for others. The mushroom growth of private and public business schools all over Pakistan has opened the possibilities for businesses/industries to have an access to qualified business graduates, at the same time students also have a wide range of choice of business institutes both from private and public to pick from, unlike in 1990s when there were only a couple of good Business Schools. On the one hand, students have the opportunity to pick up an institute of their choice but the flip side is even more challenging, how was the selected school being looked-upon by the business houses all over Pakistan. Many institutions in Pakistan came up with proper infrastructure and their graduates are the key personnel of various reputed multinational and national firms. Beside a very wide gap in quality of education (except in few) between public and private institutes, there is a very close competition among these institutes. The market acceptability of graduates produced by these institutes is always a question in either situation. This study is based upon the comparison b/w graduates of selected leading business schools of the country.
\end{abstract}

\section{Introduction:}

The importance of education is quite clear. It is the knowledge of putting one's potentials to maximum use. Simply a human being is not worthy in the proper senses till he/she is educated. The French revolutionary Danton said more than two centuries ago, "After Bread, Education Speech by Dr. Oscar Arias, October 8, 2001, Gate Annual Conference, San Jose, Costa Rica, Retrieved from < www.arias.or.cr/fundador/speeches/GATE081001.htm>" Education can train a human's mind and made him/her a right thinker. It enabled individuals to receive information from the external world to get acquainted himself/herself with necessary information regarding the present.

\section{Statistics literacy rate in Pakistan:}

- Total Adult Literacy Rate : 55\% - (UNICEF Pakistan Statistics 2007)

- Total Adult Literacy Rate : 54\% ( Male 66.25\%, Female 41.75\%) (Ministry of Education) 
- Punjab : 60.8\% (Male 70\%, Female 51\%)

- $\quad$ NWFP : $47.4 \%$ (Male 63\%, Female 30.8\%)

- $\quad$ Sindh : $5.15 \%$ (Male $60.5 \%$, Female $42.5 \%$ )

- Balochistan : 34\% (Male 45\%, Female 23\%)

- Total Literacy Rate : 49\% (Wiki Ranking)

- Total Literacy Rate 50\% (CIA Factbook-Est 2005)

Besides the great importance of education, the situation is worst in the developing world, more than 836 million adults are illiterate, around the world more than one third of adolescents are not in high schools Speech by Dr. Oscar Arias, October 8, 2001, Gate Annual Conference, San Jose, Costa Rica, Retrieved from on March 2010. Being a developing country, Pakistan is not exempted from the same. Government allocates very nominal percentage of total GDP for last several years, which has not exceeded from $2.5 \%$ of GDP in the annual budgets of last several years for education Pakistan Economic Survey, 200809. Literacy rate of Countries according to statistics by UNESCO retrieved from, 2011. The literacy rate is just below 50 even after the 62 years of independence, while it is much better in the region. The following chart presents the detail:

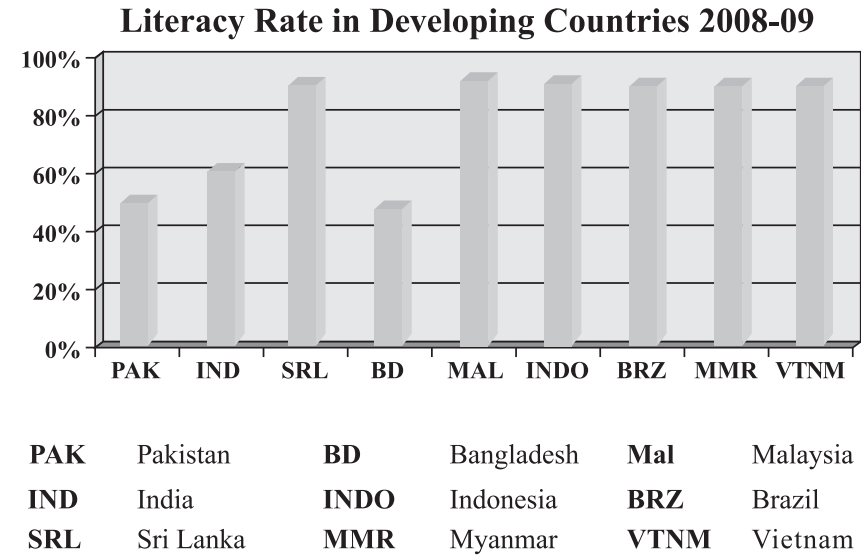

Besides the literacy rate, the quality of education is also very important in today's global environment. The quality of education imparted, is more important than the number of graduating students. In this regard, the role of private sector has been highly effective, but it further develops inequality in the society. Only a very small percentage of population can get the benefits of these very expensive institutes.

\section{Background of the study}

The unequal standard of education of various Business schools in private sector increases the frustration of graduates in Pakistan. Certain graduates from some business schools have edge over others. MBA's from all business schools are not treated at par which 
also results in a significant variation in their remuneration. To some extent, HEC is responsible for the mushroom growth of business schools but to a large extent the whole education system in the country can be blamed for this discrimination. In short; the market acceptability of graduates produced by some leading national institutes is always a question in either situation. This study is based upon the comparison of IBA business graduates versus the business graduates of LUMS, SZABIST, CBM and Iqra University.

\section{Objectives of the study}

This research may serve to achieve the following objectives:

1. The main objective to find out the market demand of business graduates in corporate sector.

2. The findings will support to produce the graduates as per market demand and to formulate the correct strategies for further improvement.

3. To help the students and parents to choose an appropriate educational institute for the higher studies.

\section{Problem statement}

The mushroom growth of private business educational institutes has made the environment highly competitive. But the real competition lies among few quality producers. IBA is one among the leading business schools of Pakistan. It has been one among the top business school of south Asia. This research is being conducted to evaluate the market acceptability of IBA business graduates versus the business graduates of LUMS, SZABIST, CBM (IoBM), and Iqra University and how IBA's MBA's are perceived in the corporate sector against the key competitors?

\section{Research questions}

1) How the corporate sector perceives of the graduates from IBA?

2) Do they prefer IBA graduates over LUMS, SZABIST, CBM (IoBM) and IQRA University?

3) How IBA graduates are better than others?

4) What IBA's position is among top three institutes?

\section{Research methodology}

This study is based on quantitative research and being conducted for the very first time. The relevant Primary data has been gathered through a questionnaire (enclosed). Some introduction and historical data have been obtained from the following secondary sources:
a. Newspapers
b. Prospectuses of selected institutes
c. Publications and reports
d. Internet

Both descriptive and inferential statistical techniques will be used to analyze the data to get appropriate conclusions. 


\section{Review of literature}

No study has been conducted so far in Pakistan over the subject. Various articles have been published in different newspapers and magazines regarding the quality of education, curriculum, faculty etc in private and public institutes. Higher Education Commission has assessed \& ranked on the basis of qualified faculty, research facilities, curriculum etc. Regardless of the high claims of quality and standard of education, the acceptance of a graduate in Job market is above every criteria and established standard. We did not find any published material over the subject.

\section{Leading business schools in Pakistan}

Lahore University of Management Sciences (LUMS): LUMS was established in 1985. It is a national university, established by sponsors belonging to the country's leading private and public sector corporations. The goal of the sponsors was to develop an institution, which would provide rigorous academic and intellectual training and a viable alternative to education comparable to leading universities around the world About and History of Lahore University of Management Sciences, Retrieved from on May 30, 2011

College of Business Management (CBM): The College of Business Management (CBM) also known as Institute of Business Management (IoBM), Karachi has been making efforts to excel in all the four areas in quality of teaching, regular updating of curricula, quantum and quality of research and training for the faculty. It is the only business school in Pakistan, with a full fledged research program and publishes the business research journal. It also offers foreign language courses (Arabic, French and German) as part of its BBA (Hon) curriculum. A curriculum committee ensures that programs are regularly revised to keep abreast changes in business education About and History of Institute of Business Management, Retrieved from on May 30, 2011.

Institute of Business Administration (IBA): IBA has the longest history of imparting education in management sciences. It is the oldest centre for business education in the country. It has a history of 50+ years. Many reputed local, multinational and transnational companies operating in Pakistan look towards IBA for their need for professional managers. The IBA was established in 1955 as a USAID financed project. Initially the Wharton School of Finance, University of Pennsylvania, provided the technical support; later, the University of Southern California got the contract to set up various facilitiesat the Institute and several prominent American professors were assigned to the IBA. Till 1994, the University of Karachi awarded degrees to the graduates. In-spite of a rapid increase in the number of business schools, the IBA has maintained its position as the premier institute of higher learning in the field of management and business administration. Daily Dawn, March 8, 2006.

Iqra University: IQRA University was chartered by the Government having campuses in federal and the provincial capitals of our country with collaborations with top foreign universities. IQRA University is a world class institution of higher education and research, dedicated to help develop a prosperous and progressive society. They offer a diverse range of graduate and post graduate courses as well as $\mathrm{PhD}$ programmes of international level in Management Sciences, Computer Sciences and IT, Development Studies, ÊAdvertising and Fashion Design.

Shaheed Zulfikar Ali Bhutto Institute of Science and Technology (SZABIST): SZABIST has a very brief history of around 15 years but the institute has been among the top number two in Pakistan and number 28 in Asia on the basis 
of a survey conducted by Asia week for the year 1999. The Institute is among the first few educational institutes who developed their website to facilitate the students to know more about the Institute and the courses offered. SZABIST is a fully Chartered Institute established through a Legislative Act of the Sindh Assembly (Sindh Act No. XI of 1995) and is approved and recognized by the Higher Education Commission (HEC), Pakistan, as a degree granting institution. SZABIST has campuses in Karachi, Islamabad, Larkana and Dubai.

\section{Frame work of analysis}

This study is based on the quantitative research and is being conducted very first time. Both descriptive and inferential statistical techniques have been used to analyze the data and reach appropriate conclusions. A model is formulated using Hypotheses test by ttest and then validated by ANOVA-test and $p$-value to find and validate the statistical significance of 5 different variables like, Academically Strong, Socially Strong, Higher IQ level, Vast Business Knowledge, and Motivational Leadership Qualities. These are vital to evaluate the market acceptability of Business graduates in corporate sectors. These variables have given appropriate weights with respect to their ranks to test the hypotheses like:

\begin{tabular}{|c|c|}
\hline RANK AND WEIGHTAGE \\
\hline Rank 1 & 10 \\
\hline Rank 2 & 08 \\
\hline Rank 3 & 06 \\
\hline Rank 4 & 04 \\
\hline Rank 5 & 02 \\
\hline NA & 00 \\
\hline
\end{tabular}

All these tests were conducted at the 0.05 significance level thereby minimizing Type-I, error with a $95 \%$ confidence level of measurement.

\section{Hypothesis}

Based on the framework of analysis, research question and problem statement, the following hypotheses statements have been developed:

1. Ho: LUMS Business graduates have greater or equal acceptance in the corporate sector than IBA business graduates.

H1: $\quad$ LUMS Business graduates do not have greater or equal acceptance in corporate sector than IBA business graduates.

2. Ho: SZABIST Business graduates have greater or equal acceptance in corporate sector than IBA business graduates.

H1: $\quad$ SZABIST Business graduates do not have greater or equal acceptance in corporate sector than IBA business graduates.

3. Ho: IBA Business graduates have greater or equal acceptance in corporate sector than CBM business graduates.

H1: $\quad$ IBA Business graduates do not have greater or equal acceptance in corporate sector than CBA business graduates. 
4. Ho: IBA Business graduates have greater or equal acceptance in corporate sector than IQRA University business graduates.

H1: $\quad$ IBA Business graduates do not have greater or equal acceptance in corporate sector than IQRA University business graduates.

\section{Population and sample}

The population of this study is the Karachi's corporate sector consists in the leading Multinationals and Nationals firms in various industries like Textile, Pharmaceuticals, leather, Automobile, Banks \& Financial Institutions, FMCG, Petroleum \& construction etc. As Karachi is the financial capital of Pakistan, so its population is very large. Out of 1768 total LSM units in Sindh 1218 are in Karachi ${ }^{9}$ besides registered firms several Medium and Small size firms are doing business in Karachi. Total 60 questionnaires have been distributed in six main industries, 39 were returned and 9 were discarded due to improper unsatisfactory answering. Finally 30 samples were selected for the study. The detail of sample distribution is as under:

TABLE 2

SAMPLE DISTRIBUTION

\begin{tabular}{|l|c|}
\hline \multicolumn{1}{|c|}{ Industries } & No. Samples \\
\hline Pharmaceutical & 06 \\
\hline Textile & 04 \\
\hline Automobile & 04 \\
\hline Electronics & 05 \\
\hline Financial Institutions & 06 \\
\hline FMCG & 05 \\
\hline TOTAL & $\mathbf{3 0}$ \\
\hline
\end{tabular}

\section{Description of variables}

Total 5 variables were incorporated in the questionnaire to rank the business graduates of selected business schools. It would have been a very long study to test all the variables equally weighted of an Independent Study. So we selected the following most effective to evaluate the leading business graduates

Academically Strong $(A S)$ : Academically strong graduates means well equipped with the latest business related subject knowledge, modern technology and teaching methodology. Qualified instructors heavily emphasize on research and publications

Socially Strong (SS): The institute enjoys great recognition at various platforms. Maximum participation in different events to represent their institute.

Higher IQ level (HIQ): Students posses' high Intelligence Quotient level.

Vast Business Knowledge (VBK): Well equipped with the basic concepts of business related theories and full awareness about various tactics of business associated areas.

Motivational Leadership Quality (MLQ): People possess great quality of leadership who may influence the people to motivate and contribute their best to their employer. 


\section{Findings of the study}

The research findings are as under:

\section{Descriptive measures}

Following table presents the Mean, Median, Mode \& standard deviation:

TABLE 3

\begin{tabular}{|l|c|c|c|c|c|}
\hline & AS & SS & HIQ & VBK & MLQ \\
\hline Mean & 237.20 & 250.80 & 156.00 & 80.40 & 146.00 \\
\hline St. Deviation & 37.88 & 19.63 & 8.12 & 11.95 & 29.50 \\
\hline Median & 246 & 252 & 160 & 78 & 138 \\
\hline Mode & 266 & 266 & 160 & 81 & 138 \\
\hline
\end{tabular}

The Above table summarizes the results for the descriptive parameters like mean, median, mode, variance, standard deviation, skewness and kurtosis generated by using MEGASTAT in Excel software to validate the assumption about normal distribution to test the hypotheses of sample and population. curve.

The Mean, Median, and Mode are very close so the variables approximating the normal distribution

\section{Hypothesis 1}

\section{Statistical Presentation}

$$
\begin{array}{ll}
\text { Ho: } & \mu 1(\text { LUMS })=\mu 2 \text { (IBA) } \\
\text { H1: } & \mu 1(\text { LUMS) }<\mu 2 \text { (IBA) }
\end{array}
$$

The summarized result is presented below:

TABLE 4

LUMS vs IBA

\begin{tabular}{|l|c|c|c|}
\hline & Mean & Standar Dev. & T-Value \\
\hline LUMS & 156 & 8.12 & \multirow{2}{*}{-4.69} \\
\hline IBA & 237 & 37.88 & \\
\hline
\end{tabular}

At $95 \%$ confidence level, $t$-calculated value is -4.69 falls in the non-critical region which is -1.86 therefore the null hypothesis is rejected. It concludes that the LUMS business graduates do not have the greater or even equal acceptance in the corporate sector in comparison to IBA or in other words the business graduates of IBA have more acceptances in the corporate sector in comparison to LUMS 


\section{Hypothesis 2}

\section{Statistical Presentation}

$$
\begin{array}{ll}
\text { Ho: } & \mu 1 \text { (Szabist) }=\mu 2 \text { (IBA) } \\
\text { H1: } & \mu 1 \text { (Szabist) }<\mu 2 \text { (IBA) }
\end{array}
$$

The summarized result is presented below:

TABLE 5

SZABIST vs IBA

\begin{tabular}{|l|c|c|c|}
\hline & Mean & Standar Dev. & T-Value \\
\cline { 1 - 3 } SZABIT & 156 & 8.12 & \multirow{2}{*}{-9.98} \\
\cline { 1 - 3 } IBA & 250 & 19.62 & \\
\hline
\end{tabular}

At $95 \%$ confidence level, t-calculated value is -9.98 falls in the non-critical region which is -1.86 therefore the null hypothesis is rejected. It concluded, the SZABIST business graduates do not have the greater or even equal acceptance in the corporate sector in comparison to IBA or in other words the business graduates of IBA have more acceptance in the corporate sector in comparison to SZABIST graduates.

\section{Hypothesis 3}

\section{Statistical presentation}

Ho: $\quad \mu 1($ IBA $)=\mu 2($ CBA $)$

H1: $\quad \mu 1($ IBA $)<\mu 2($ CBM $)$

The summarized result is presented below:

TABLE 6

IBA vs CBM

\begin{tabular}{|l|c|c|c|}
\hline & Mean & Standar Dev. & T-Value \\
\hline IBA & 156 & 8.12 & \multirow{2}{*}{0.73} \\
\hline CBM & 146 & 29.496 & \\
\hline
\end{tabular}

At $95 \%$ confidence level, $t$-calculated value 0.73 is greater than t-tabulated value 1.86 therefore the null hypothesis is not rejected. It concludes that the IBA business graduates have greater or even equal acceptance in the corporate sector in comparison to $\mathrm{CBM}$ or in other words the business graduates of CBM do not have more acceptance in the corporate sector in comparison to IBA 


\section{Hypothesis 4}

\section{Statistical presentation}

Ho: $\quad \mu 1($ IBA $)=\mu 2$ (IQRA)

H1: $\quad \mu 1($ IBA $)<\mu 2$ (IQRA)

The summarized result is presented below:

TABLE 7

IBA vS IQRA

\begin{tabular}{|l|c|c|c|}
\hline & Mean & Standar Dev. & \multirow{2}{*}{ T-Value } \\
\hline IBA & 156 & 8.12 & \multirow{2}{*}{11.70} \\
\hline IQRA & 80.40 & 11.95 & \\
\hline
\end{tabular}

At $95 \%$ confidence level, $t$-calculated value 11.70 is greater than t-tabulated value -1.86 therefore the null hypothesis is not rejected. It concludes that the IBA business graduates have greater or even equal acceptance in the corporate sector in comparison of business graduates of IQRA University or in other words the business graduates of IQRA University do not have more acceptances in the corporate sector in comparison to IBA.

\section{Qualitative analysis of the data}

The qualitative analyses of determinants such as (a) Variable-wise ranking (b) Institutions ranking-wise (c) Percentage of opinions (d) Overall ranking of Institutions is given below:

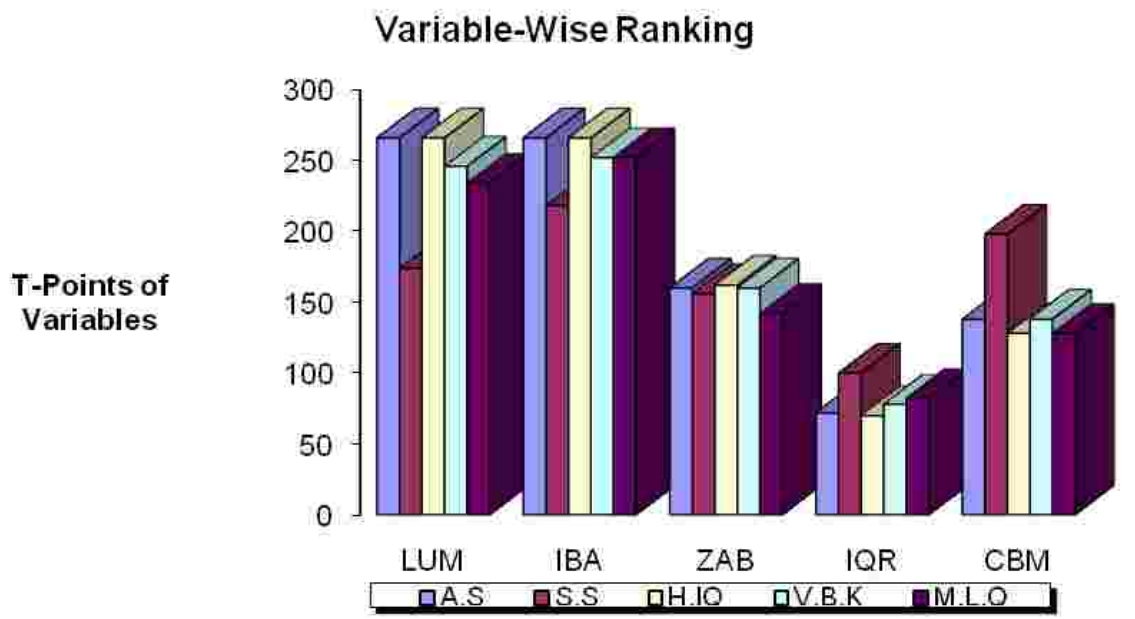



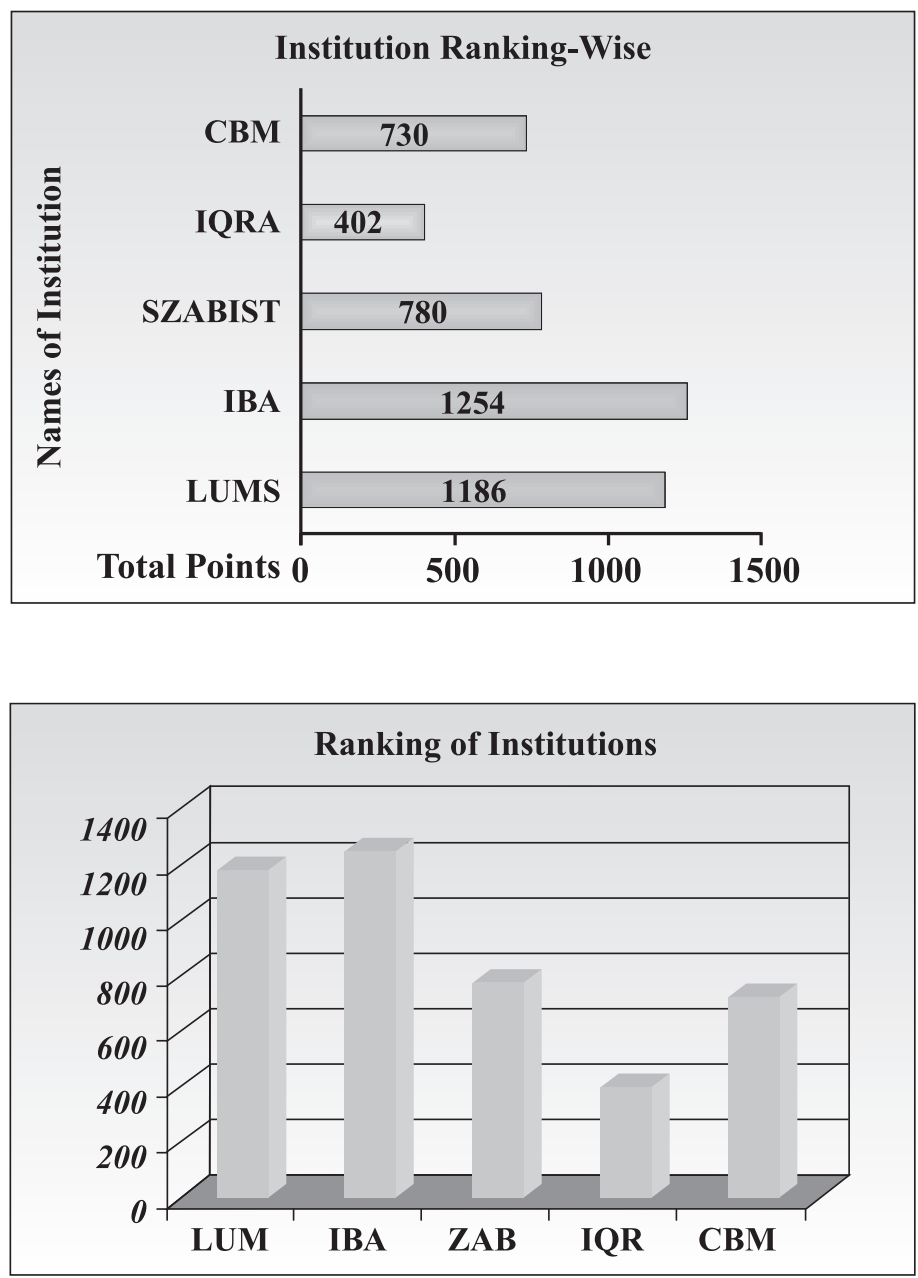

\section{Percentage of Opinions}

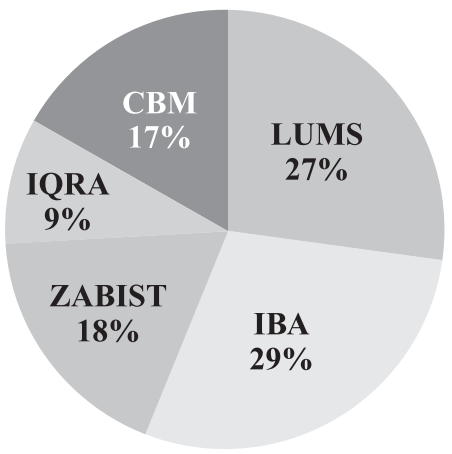




\section{Conclusions}

This study has been conducted to evaluate the market acceptability of Business Graduates of IBA. Overall it could be concluded that the business graduates of IBA have developed and sustained good market acceptability in last 50 years. At present it enjoys \#1 position after it LUMS at number two position, whereas, the SZABIST has a third position in corporate sector. Before the study it was assumed that LUMS enjoyed no. 1 position. The graphical representation shows the overall ranking of the institutions. From the qualitative analysis it has been concluded that the IBA has secured first position by taking 1254 points, whereas, the LUMS stood second securing 1186 point and the SZABIST the third position by obtaining 780 points. So, finally, it has been concluded that the IBA is the best choice by the respondents which has been taken from the corporate sector.

\section{Recommendations}

By looking at the statistical findings of the study, it is recommended that the management of IBA should carefully evaluate the weak areas vs. its importance given by the corporate sector for a business graduate. Even though IBA's emphasis on research work \& technology orientation is high, it still needs to evaluate its academic curriculum and bring it in-line with the other business schools.

\section{Suggested areas for further study}

Considering the findings of this report based on the selected five variables it is highly recommended to extend the scope of this study by evaluating the other aspects of a good business graduate school. Similarly the span of the industries or corporate sector should also be diversified for its in-depth findings.

\section{Limitations}

There is no big limitation except shortage of time. More variables may have been incorporated in this study, if time permitted. People in corporate sector extend their high support and fill out the questionnaire with great enthusiasm as this type of study is being conducted for the first time in Pakistan.

\section{Acknowledgments}

The group is highly appreciative of the dedicated support of Mr. Ahmed Afraz, Mr. Ali Merchant, Mr. Shahzad Qasim, Mr. Syed Sarwar Kazim, Mr. Waqar Ahmed and Mr. Abdul Hayat Khan for the completion of this research study. We are also thankful to Mr. Saleem Umer (Director EMBA- IBA) who provided us the chance \& gave us confidence to pursue this research as a partial fulfillment of Statistics and Business Mathematics course.

\section{References}

Speech by Dr. Oscar Arias, (October 8, 2001), Gate Annual Conference, San Jose, Costa Rica, Retrieved from www.arias.or.cr/fundador/speeches/GATE081001.htm

Arias, O., (2001) Importance of Education Retrieved from

http://www.alrisala.org/Articles/mailing_list/importance_of_education

Pakistan Economic Survey, 2008-09 
(2010) Literacy rates of Countries according to statistics by UNESCO retrieved from http://en.wikipedia.org/wiki/List_of_countries_by_literacy_rate on May 30

Pakistan Economic Survey, 2004-05

(May 30, 2010) About and History of Institute of Business Management, Retrieved from http/www.cbm.edu.pk

Daily Dawn, March 8, 2006

(May 30, 2010) About and History of Lahore University of Management Sciences, Retrieved from http/www.lums.edu.pk

(May 30, 2010) About and History of Institute of Business Administration, Retrieved from http/www.iba.edu.pk

(May 30, 2010) About and History of Shaheed Zulfiqar Ali Bhutto Institute of Science and Technology, Retrieved from http/www.szabist.edu.pk

Vishnu P. (2004). Investment Trend in Hyderabad" Independent Study, JISR, (szabist) Vol. 3. No. 2 page 16 .

Only in man has the evolution of the creation reached the point where reality encounters itself in judgment and choice. Outside of man the creation is neither good nor evil. Only when you descend into yourself and encounter the Other, do you then experience goodness as the ultimate reality - united and living - in Him and through you.

- Dag Hammarskjold, Markings, P.165 